\title{
A Simple and Sensitive Method for the Determination of Hydroxylamine in Fresh-Water Samples Using Hypochlorite Followed by Gas Chromatography
}

\author{
Yasushi SeIKe, ${ }^{* \dagger}$ Ryoko Fukumori,* Yukiko Senga,** Hiroki OKa,* Kaoru FujINAGa,* and \\ Minoru OKUMURA* \\ *Faculty of Science and Engineering, Shimane University, 1060, Matsue, Shimane 690-8504, Japan \\ **Faculty of Life and Environmental Science, Shimane University, 1060, Matsue, Shimane 690-8504, Japan
}

\begin{abstract}
A new and simple method for the determination of hydroxylamine in environmental water, such as fresh rivers and lakes using hypochlorite, followed by its gas choromatographic detection, has been developed. A glass vial filled with sample water was sealed by a butyl-rubber stopper and aluminum cap without head-space, and then sodium hypochlorite solution was injected into the vial through a syringe to convert hydroxylamine to nitrous oxide. The head-space in the glass vial was prepared with $99.9 \%$ grade $\mathrm{N}_{2}$ using a gas-tight syringe. After the glass vial was shaken for a few minutes, nitrous oxide in the gas-phase was measured by a gas chromatograph with an electron-capture detector. The dissolved nitrous oxide in the liquid-phase was calculated according to the solubility formula. The proposed method was applied to the analysis of fresh-water samples taken from Iu river and Hii river, flowing into brackish Lakes Nakaumi and Shinji, respectively.
\end{abstract}

(Received September 17, 2003; Accepted November 13, 2003)

\section{Introduction}

Nitrogenous species, such as ammonia, nitrite, nitrate, hydroxylamine $\left(\mathrm{NH}_{2} \mathrm{OH}\right)$ and nitrous oxide $\left(\mathrm{N}_{2} \mathrm{O}\right)$, are recycling through microbial processes in the hydrosphere. ${ }^{1-3} \mathrm{NH}_{2} \mathrm{OH}$ has been identified as an intermediate in the nitrogen cycles, such as the oxidation of ammonia to nitrite and the reduction of nitrite to ammonia by several microorganisms in aquatic and sedimentary systems. ${ }^{4,5}$ Furthermore, $\mathrm{NH}_{2} \mathrm{OH}$ is often described as an intermediate for producing $\mathrm{N}_{2} \mathrm{O} . \quad \mathrm{N}_{2} \mathrm{O}$ is one of the greenhouse gases, and is also associated with the reduction of ozone in the stratosphere. Hence, $\mathrm{NH}_{2} \mathrm{OH}$ is an important nitrogen species not only for understanding the nitrogen cycle, but also for clarifying the mechanism of $\mathrm{N}_{2} \mathrm{O}$ production.

It has been reported that millimolar solutions of $\mathrm{NH}_{2} \mathrm{OH}$ are stable for several hours at $\mathrm{pH} 4.0$, but only for $60 \mathrm{~min}$ at $\mathrm{pH} 7.8$ in the presence of air. ${ }^{6,7}$ Thus, the direct determination of $\mathrm{NH}_{2} \mathrm{OH}$ is difficult in environmental water because of its low concentration and instability. ${ }^{8}$ Several methods, such as spectrophotometric methods ${ }^{6,9-11}$ and a titrimetric method ${ }^{12}$ for the determination of $\mathrm{NH}_{2} \mathrm{OH}$, have been reported. The former method is based on the combination of the oxidation of $\mathrm{NH}_{2} \mathrm{OH}$ to nitrite with iodine and the usual Griess-Romijin method. This method, however, is subject to interference from nitrite..$^{13}$ The latter method is based on the oxidation of $\mathrm{NH}_{2} \mathrm{OH}$ using ferric ammonium sulfate with a copper sulfate catalyst. In this method, $\mathrm{Fe}$ (III) was reduced by $\mathrm{NH}_{2} \mathrm{OH}$ and the resultant $\mathrm{Fe}$ (II) was titrated with potassium dichromate. This method is

$\doteqdot$ To whom correspondence should be addressed.

E-mail: yseike@ riko.shimane-u.ac.jp applicable in the millimolar range. In general, these methods were employed only in media containing a relatively high concentration of $\mathrm{NH}_{2} \mathrm{OH}$. On the other hand, Marta et al. developed a gas chromatographic method for the determination of nanomolar concentrations of $\mathrm{NH}_{2} \mathrm{OH}$ by its oxidation to $\mathrm{N}_{2} \mathrm{O}$ using $\mathrm{Fe}(\mathrm{III})$ ions. ${ }^{14}$ However, the yield for the conversion of $\mathrm{NH}_{2} \mathrm{OH}$ to $\mathrm{N}_{2} \mathrm{O}$ by this method was $50 \%$.

In a previous paper, ${ }^{13}$ we reported the spectrophotometric determination for $\mathrm{NH}_{2} \mathrm{OH}$ in environmental water samples. The interference from nitrite in the water sample described above was solved by removing the resultant azo dye from nitrite using a Sep-Pak $\mathrm{C}_{18}$ cartridge prior to the analysis of $\mathrm{NH}_{2} \mathrm{OH}$. Although this method was available for environmental water samples from fresh-water to seawater, the procedure was very tedious. In this paper, we propose a new and simple method for the determination of nanomolar $\mathrm{NH}_{2} \mathrm{OH}$ in fresh-water samples by its oxidation to nitrous oxide using hypochlorite as an oxidizing agent. The $\mathrm{N}_{2} \mathrm{O}$ produced in this manner was subsequently measured by using a gas chromatograph with an electron-capture detector (ECD).

\section{Experimental}

\section{Reagent and apparatus}

Reagent solutions were prepared with high-purity water from a Millipore Milli-Q purification system. A standard $\mathrm{NH}_{2} \mathrm{OH}$ solution $\left(500 \mathrm{mgN} \mathrm{L}^{-1}\right.$ ) was prepared by dissolving $0.2481 \mathrm{~g}$ of hydroxylammonium chloride in $100 \mathrm{~mL}$ of water deoxidated with nitrogen gas. It was fleshly prepared for each analysis. A hypochlorite solution was prepared by adding $2.5 \mathrm{~mL}$ of commercially available sodium hypochlorite solution (5\% 


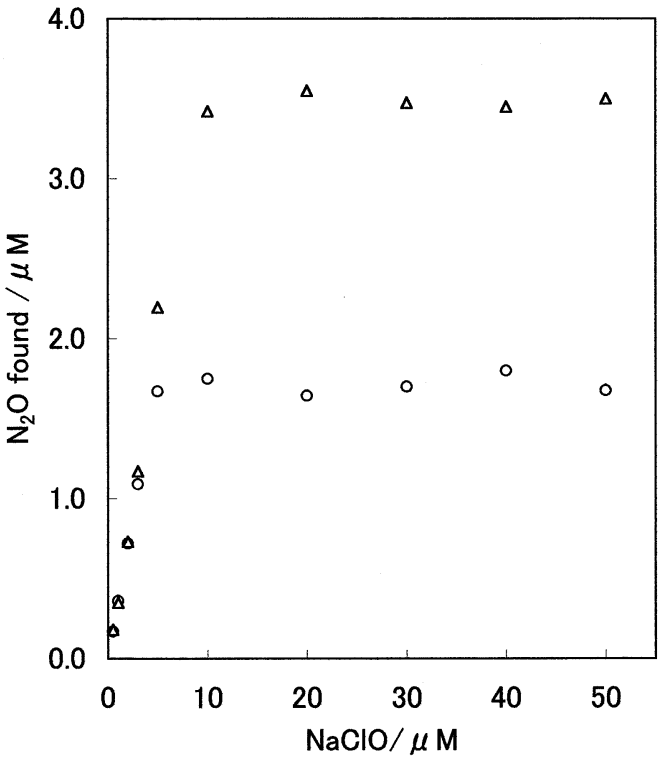

Fig. 1 Effect of hypochlorite on the oxidation of hydroxylamine to nitrous oxide. The concentrations of $\mathrm{NH}_{2} \mathrm{OH}$ added were $3.57 \mu \mathrm{M}$ $\left(50 \mu \mathrm{gN} \mathrm{L}^{-1}\right)(\mathrm{O})$ and $7.14 \mu \mathrm{M}\left(100 \mu \mathrm{gN} \mathrm{L}^{-1}\right)(\Delta)$, respectively.

available chlorine) into $1000 \mathrm{~mL}$ of water. A calibration gas, 99.5\% grade nitrous oxide $\left(\mathrm{N}_{2} \mathrm{O}\right)$ was diluted to the desired concentration with $99.9 \%$ grade $\mathrm{N}_{2}$. Artificial seawater was prepared by dissolving $\mathrm{NaCl}, \mathrm{MgCl}_{2}, \mathrm{Na}_{2} \mathrm{SO}_{4}, \mathrm{CaCl}_{2}, \mathrm{KCl}$, $\mathrm{NaHCO}_{3}, \mathrm{KBr}, \mathrm{H}_{3} \mathrm{BO}_{3}, \mathrm{SrCl}_{2}$ and $\mathrm{NaF}$ in $1 \mathrm{~kg}$ of water, according to Lyman and Fleming's procedure. ${ }^{15}$

A Shimadzu GC-14B-type gas chromatograph with an electron-capture detector (ECD) was used to determine $\mathrm{N}_{2} \mathrm{O}$. Each $\mathrm{pH}$ value in solution was measured with a Horiba F-23 type $\mathrm{pH}$ meter.

\section{Condition of gas chromatography}

A 2-m long stainless-steel column of $2.6 \mathrm{~mm}$ i.d. packed with Unibeads C (80/100 mesh) was used at an oven temperature of $130^{\circ} \mathrm{C}$. Each temperature of injection and detector (ECD) was 200 and $300^{\circ} \mathrm{C}$, respectively. A carrier gas, $99.99995 \%$ grade $\mathrm{N}_{2}$, was used at a rate of $50 \mathrm{~mL} \mathrm{~min}{ }^{-1}$.

\section{Standard procedure}

A sample was transferred into a $70-\mathrm{mL}$ glass vial. The vial was sealed by a butyl-rubber stopper and aluminum cap without any head-space, and then $1 \mathrm{~mL}$ of a hypochlorite solution was injected to oxidize $\mathrm{NH}_{2} \mathrm{OH}$ to $\mathrm{N}_{2} \mathrm{O}$. A small glass ball was included inside for mixing the solution. The head-space technique was used to determine the resultant $\mathrm{N}_{2} \mathrm{O}$ in the sample. The head-space of the glass vial was prepared with 99.9\% grade $\mathrm{N}_{2}$ using a gas-tight syringe. After the glass vial was shaken for a few minutes, $\mathrm{N}_{2} \mathrm{O}$ in the gas-phase was measured by a gas chromatograph with ECD. The $\mathrm{N}_{2} \mathrm{O}$ dissolved in the liquid-phase was calculated by the solubility formula of Weiss and Price. ${ }^{16} \quad \mathrm{~A} \mathrm{~N}_{2} \mathrm{O}$ blank for each sample was measured without the addition of a hypochlorite solution. This gave the original amount of dissolved $\mathrm{N}_{2} \mathrm{O}$ in the samples. $\mathrm{NH}_{2} \mathrm{OH}$ was calculated as $\Delta \mathrm{N}_{2} \mathrm{O}$, which is the difference between the $\mathrm{N}_{2} \mathrm{O}$ present in the samples treated and untreated with hypochlorite solution. The detection limit of this gas chromatography for $\mathrm{N}_{2} \mathrm{O}$ was $0.1 \mu \mathrm{gN} \mathrm{L} \mathrm{L}^{-1}$.

In field studies, formaldehyde ( $1 \%$ final concentration) was injected into the sample to stop the biological activity for the

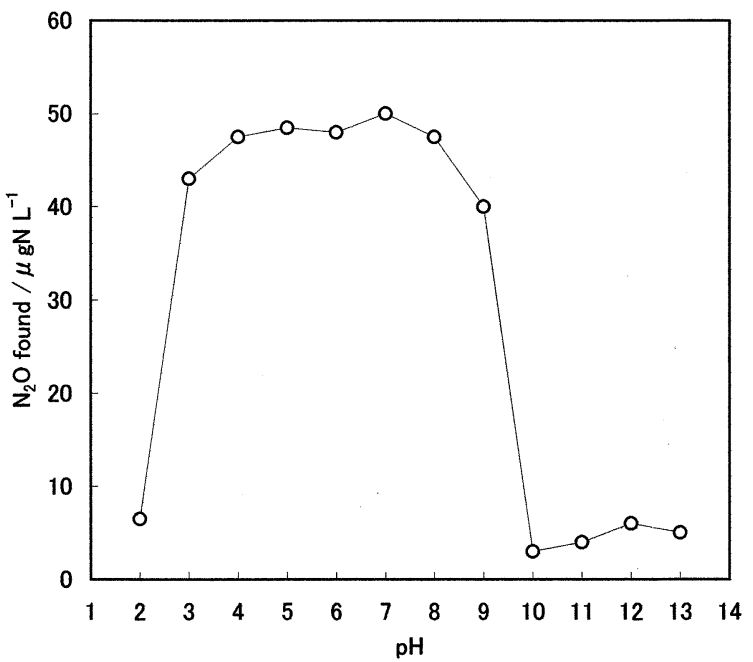

Fig. 2 Effect of $\mathrm{pH}$ on the oxidation of hydroxylamine $(50 \mu \mathrm{gN}$ $\mathrm{L}^{-1}$ ) to nitrous oxide.

original $\mathrm{N}_{2} \mathrm{O}$ analysis. For another sample, $1 \mathrm{~mL}$ of a hypochlorite solution was injected to oxidize $\mathrm{NH}_{2} \mathrm{OH}$ to $\mathrm{N}_{2} \mathrm{O}$. Both procedures were carried out in situ immediately after sampling. The resulting solutions were brought back to the laboratory for gas chromatographic measurements.

\section{Results and Discussion}

Optimum condition for the oxidation of hydroxylamine to nitrous oxide

Effect of hypochlorite concentration. The optimum concentration of the hypochlorite solution for the production of $\mathrm{N}_{2} \mathrm{O}$ from $\mathrm{NH}_{2} \mathrm{OH}$ was examined in 3.57 and $7.14 \mu \mathrm{M}(50$ and $100 \mu \mathrm{gN} \mathrm{L}^{-1}$ ) of $\mathrm{NH}_{2} \mathrm{OH}$ standard solutions, respectively. As shown in Fig. 1, each recovery from 3.57 and $7.14 \mu \mathrm{M}$ of $\mathrm{NH}_{2} \mathrm{OH}$ was approximately $100 \%$, when the concentration of hypochlorite solution was higher than 5 and $10 \mu \mathrm{M}$, respectively. Thus, the concentration adopted in the proposed method was $50 \mu \mathrm{M}$ of a hypochlorite solution.

According to the relationship between the added $\mathrm{NH}_{2} \mathrm{OH}$ and the produced $\mathrm{N}_{2} \mathrm{O}$ by the reaction with hypochlorite (data not shown), the resultant $\mathrm{N}_{2} \mathrm{O}$ agreed with the theoretical values calculated using Eq. (1). Thus, the oxidation of $\mathrm{NH}_{2} \mathrm{OH}$ to $\mathrm{N}_{2} \mathrm{O}$ by hypochlorite was found to proceed stoichiometrically as follows:

$$
2 \mathrm{NH}_{2} \mathrm{OH}+2 \mathrm{NaClO} \longrightarrow \mathrm{N}_{2} \mathrm{O}+2 \mathrm{NaCl}+3 \mathrm{H}_{2} \mathrm{O}
$$

Effect of standing time. After adding the hypochlorite solution, the highest recovery was $10 \mathrm{~min}$, indicating that the oxidation reaction of $\mathrm{NH}_{2} \mathrm{OH}$ to $\mathrm{N}_{2} \mathrm{O}$ by hypochlorite was completed in 10 min. The resultant $\mathrm{N}_{2} \mathrm{O}$ was stable for at least 10 days.

Effect of $\mathrm{pH}$. The effect of $\mathrm{pH}$ on the oxidation of $\mathrm{NH}_{2} \mathrm{OH}$ to $\mathrm{N}_{2} \mathrm{O}$ was examined by adjusting the $\mathrm{pH}$ of solution with dilute hydrochloric acid and a dilute sodium hydroxide solution. As shown in Fig. 2, the highest, constant recovery was obtained at between $\mathrm{pH}$ values of 4 and 8 .

Effect of diverse ions. In aquatic environments, nitrogen species other than $\mathrm{NH}_{2} \mathrm{OH}$, such as ammonium, nitrite, nitrate, urea, and amino acid, are present. The influences of such nitrogenous compounds on the determination of $\mathrm{NH}_{2} \mathrm{OH}$ were examined in 


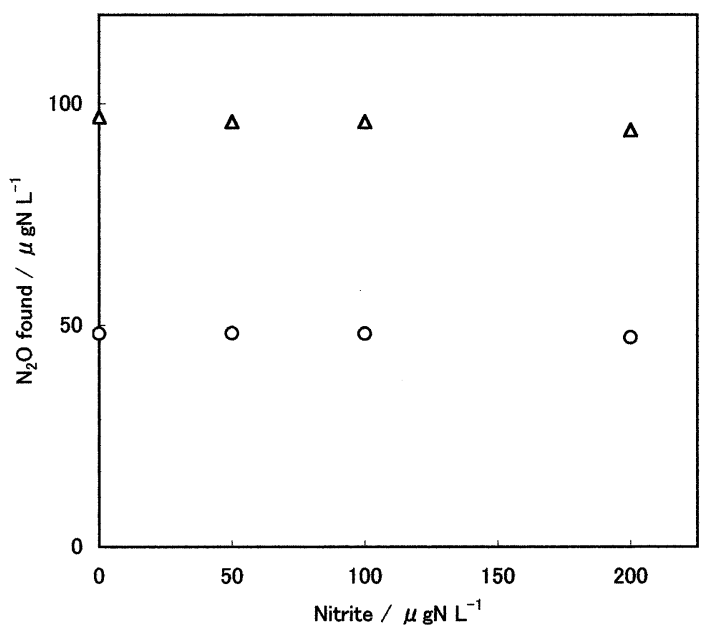

Fig. 3 Effect of nitrite on the oxidation of hydroxylamine to nitrous oxide. $\mathrm{NH}_{2} \mathrm{OH}: \circ, 50 \mu \mathrm{gN} \mathrm{L}^{-1} ; \Delta, 100 \mu \mathrm{gN} \mathrm{L}^{-1}$.

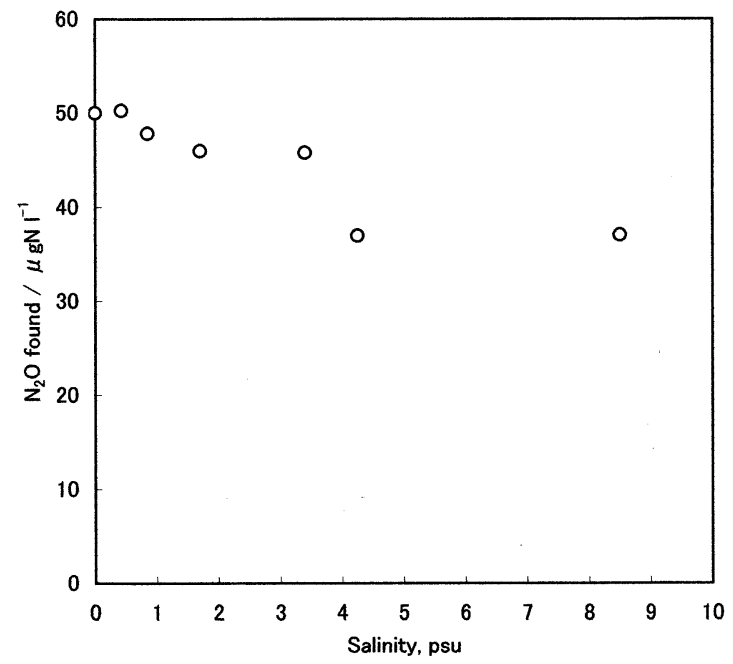

Fig. 4 Effect of salinity in the presence of ammonia $(1000 \mu \mathrm{gN}$ $\mathrm{L}^{-1}$ ) on the oxidation of hydroxylamine to nitrous oxide.

the range of concentration for each species in nature. Figure 3 shows the effect of nitrite on the recovery of $\mathrm{NH}_{2} \mathrm{OH}$ to $\mathrm{N}_{2} \mathrm{O}$ by the proposed method. The recoveries of $\mathrm{NH}_{2} \mathrm{OH}$ were very favorable in the range of $0-200 \mu \mathrm{gN} \mathrm{L}^{-1}$ of nitrite. As reported in a previous paper, nitrite interfered with the determination of $\mathrm{NH}_{2} \mathrm{OH}$ using the iodine oxidation technique. Fortunately, nitrite did not interfere with the proposed method. In the range of $0-2000 \mu \mathrm{gN} \mathrm{L}^{-1}$, major nitrogen species, such as ammonium and nitrate, did not interfere with the proposed method (data not shown). In addition, as shown in Table 1, neither several amino acids nor urea interfered with the proposed method.

For the purpose of applying the proposed method to brackishwater and seawater samples, the influence of salinity on the determination of $\mathrm{NH}_{2} \mathrm{OH}$ was also examined using artificial seawater and its dilute solutions. Figure 4 shows the effect of the coexisting salinity and ammonia on the recovery of $\mathrm{NH}_{2} \mathrm{OH}$ to $\mathrm{N}_{2} \mathrm{O}$. In the presence of ammonia $\left(1000 \mu \mathrm{gN} \mathrm{L}^{-1}\right)$, the recovery of $\mathrm{NH}_{2} \mathrm{OH}$ to $\mathrm{N}_{2} \mathrm{O}$ decreased with increasing the salinity to more than $1.0 \mathrm{psu}$. Unfortunately, we found that the proposed method was not applicable to the determination of $\mathrm{NH}_{2} \mathrm{OH}$ in brackish water.
Table 1 Effects of amino acids and urea on the recovery of hydroxylamine

\begin{tabular}{lrr}
\hline \multicolumn{1}{c}{ Sample } & \multicolumn{2}{c}{ Found/ Recovery, } \\
& $\mu \mathrm{gN} \mathrm{L}^{-1}$ & $\%$ \\
\hline $\mathrm{NH}_{2} \mathrm{OH}(50)$ only & 49.6 & - \\
Glycine $(100)+\mathrm{NH}_{2} \mathrm{OH}(50)$ & 47.8 & 96.4 \\
L-Lysine monohydrochloride (100) $+\mathrm{NH}_{2} \mathrm{OH}(50)$ & 48.2 & 97.2 \\
L-Glutamic acid (100) $+\mathrm{NH}_{2} \mathrm{OH}(50)$ & 51.1 & 103.0 \\
L-Phenylalanine $(100)+\mathrm{NH}_{2} \mathrm{OH}(50)$ & 48.4 & 97.6 \\
L- $\alpha$-Alanine $(100)+\mathrm{NH}_{2} \mathrm{OH}(50)$ & 47.6 & 96.0 \\
Urea $(100)+\mathrm{NH}_{2} \mathrm{OH}(50)$ & 49.3 & 99.4 \\
\hline
\end{tabular}

a. The values in parentheses are the concentration of each substance in $\mu \mathrm{gN} \mathrm{L}^{-1}$.

Table 2 Recovery of hydroxylamine added to fresh-water ${ }^{\mathrm{a}}$

\begin{tabular}{ccrcc}
\hline Sample & $\begin{array}{c}\text { Added/ } \\
\mu \mathrm{gN} \mathrm{L}^{-1}\end{array}$ & $\begin{array}{c}\text { Found/ } \\
\mu \mathrm{gN} \mathrm{L}^{-1}\end{array}$ & $\begin{array}{c}\text { Recovery, } \\
\%\end{array}$ & $\begin{array}{c}\mathrm{RSD}(n=5), \\
\%\end{array}$ \\
\hline Fresh-water & 0 & 1.9 & - & 3.6 \\
& 20 & 21.3 & 97.0 & 2.1 \\
& 50 & 51.5 & 99.2 & 1.4 \\
\hline
\end{tabular}

a. Fresh-water sample was taken from Mabashi river in Matsue, Japan.

\section{Recovery and reproducibility}

The recoveries of $\mathrm{NH}_{2} \mathrm{OH}$ were examined using an urban river sample in Matsue, to which various amounts of $\mathrm{NH}_{2} \mathrm{OH}$ (20 and $50 \mu \mathrm{gN} \mathrm{L}^{-1}$ ) were added. As shown in Table $2, \mathrm{NH}_{2} \mathrm{OH}$ was recovered quantitatively from the sample solution. The relative standard deviation (RSD) was $1.4-3.6 \%$ at concentrations of $2-50 \mu \mathrm{gN} \mathrm{L}^{-1}$.

Application to environmental water

The proposed method was applied to fresh-water samples taken from Iu river and Hii river, flowing into Lakes Nakaumi and Shinji, respectively. For a comparison, the same water samples were determined by using a conventional spectrophotometric method. ${ }^{13}$ For the proposed method, $1 \mathrm{~mL}$ of hypochlorite solution was injected to oxidize $\mathrm{NH}_{2} \mathrm{OH}$ to $\mathrm{N}_{2} \mathrm{O}$, immediately after sampling, and then the resulting solution was brought back to our laboratory for a gas chromatographic measurement. In the conventional method, acetic acid solution was added to a final concentration of $0.05 \mathrm{M}$ to stabilize $\mathrm{NH}_{2} \mathrm{OH}$ in the sample, immediately after sampling. The resulting solution was then brought back to our laboratory for a spectrophotometric measurement. As shown in Table 3, the results obtained by both methods are in good agreement with each other. Thus, the proposed method is satisfactorily applicable to the analysis of fresh-water such as river water and lake water.

It is predictable that $\mathrm{NH}_{2} \mathrm{OH}$ is readily oxidized by atmospheric oxygen in aquatic environments because of its extreme lability. As can be seen from Table 3, however, a high concentration of $\mathrm{NH}_{2} \mathrm{OH}, 50 \mu \mathrm{gN} \mathrm{L}^{-1}$, was found in a reed bed of Hii river. This indicates that the relative kinetics of the two competing reactions, microbial production and autoxidation, may allow the accumulation of $\mathrm{NH}_{2} \mathrm{OH}$ in aquatic environments. 
Table 3 Analytical results for environmental water samples

\begin{tabular}{lcc}
\hline \multicolumn{1}{c}{ Sampling site $^{\mathrm{b}}$} & $\begin{array}{r}\text { Proposed } \\
\text { method/ } \\
\mu \mathrm{gN} \mathrm{L}^{-1}\end{array}$ & $\begin{array}{c}\text { Conventional } \\
\mathrm{method}^{\mathrm{a}} / \\
\mu \mathrm{gN} \mathrm{L}^{-1}\end{array}$ \\
\hline Site A: Iu river & & \\
A-1: Upstream $(<0.1 \mathrm{psu})$ & 0.5 & $<1.0$ \\
A-2: Upper stream in town $(<0.1 \mathrm{psu})$ & 1.7 & 1.8 \\
A-3: Middle stream in town $(<0.1 \mathrm{psu})$ & 1.9 & 1.9 \\
A-4: Down stream in town $(<0.1 \mathrm{psu})$ & 1.3 & 1.5 \\
A-5: Near estuary $(0.30$ psu $)$ & 2.1 & 2.0 \\
Site B: Hii river & 6.6 & 6.2 \\
B-1: Near estury (<0.1 psu) & 0.3 & $<1.0$ \\
B-2: Estury $(0.18$ psu) & 50.6 & 49.2 \\
B-3: Reed bed in estury $(0.21 \mathrm{psu})$ & \\
\hline
\end{tabular}

a. Hydroxylamine in environmental water sample was spectrophotometrically determined by the iodine oxidation method with 50 -mm glass cell. ${ }^{13}$

b. Water samples of the sites A and B were taken from Iu river and Hii river, Japan, on July 19 and February 5, 2003, respectively.

\section{Conclusion}

In this study, a new and simple method for the determination of hydroxylamine in an aquatic environment was developed. Hydroxylamine in a fresh-water sample was oxidized quantitatively to nitrous oxide by using hypochlorite as an oxidizing agent. The nitrous oxide produced in this manner was subsequently measured by a gas chromatograph with an electron-capture detector. The relative standard deviation was $1.4-3.6 \%$ at hydroxylamine concentrations of $2-50 \mu \mathrm{gN} \mathrm{L}^{-1}$.

\section{Acknowledgements}

This study was partly supported by a Grant-in-Aid for Scientific Research (No. 14380243) from the Ministry of Education, Culture, Sports, Science and Technology, Japan.

\section{References}

1. Y. Seike, K. Kondo, H. Hashitani, M. Okumura, K. Fujinaga, and Y. Date, Jpn. J. Limnol., 1990, 51, 137.

2. Y. Senga, Y. Seike, K. Mochida, K. Fujinaga, and M. Okumura, Limnology, 2001, 2, 129.

3. Y. Senga, K. Mochida, N. Okamoto, R. Fukumori, and Y. Seike, Limnology, 2002, 3, 21.

4. T. Hofman and H. Lees, Biochem. J., 1952, 54, 579.

5. M. Tanaka, Nature, 1953, 171, 1160.

6. M. Fiadeiro, L. Solorzano, and J. D. H. Strickland, Limnol. Oceanogr., 1967, 12, 555.

7. J. H. Anderson, Analyst, 1954, 89, 357.

8. L. R. Pittwell, "Mikrochimica Acta [Wien] 1975 II", 1975, Springer-Verlag Press.

9. G. Endres and L. Kaufmann, Ann. Chem., 1937, 530, 184.

10. R. Novak and P. W. Wilson, J. Bact., 1948, 55, 517.

11. T. Z. Csaky, Acta Chem. Scand., 1949, 2, 450.

12. K. B. Rao and G. G. Z. Rao, Anal. Chem., 1942, 64, 731.

13. R. Fukumori, Y. Senga, M. Okumura, K. Fujinaga, and Y. Seike, Bunseki Kagaku, 2003, 52, 747.

14. M. T. von Breymann, M. A. de Angells, and L. I. Gordon, Anal. Chem., 1982, 54, 1209.

15. J. P. Riley and G. Skirrows, "Chemical Oceangraphy 1", 1965, Academic Press, New York, 648.

16. R. F. Weiss and B. A. Price, Mar. Chem., 1980, 8, 347. 